\title{
Actual Nutrition as a Criterion for Assessing the Children and Adolescents Health in Ukraine
}

\author{
Shchudro Svetlana Anatolievna \\ Hygiene and Ecology Department, Dnipropetrovsk Medical Academy Ministry of Public Health of Ukraine, Dnipro City, Ukraine
}

Email address:

shchudrosvetlana@gmail.com

\section{To cite this article:}

Shchudro Svetlana Anatolievna. Actual Nutrition as a Criterion for Assessing the Children and Adolescents Health in Ukraine. Psychology and Behavioral Sciences. Vol. 6, No. 5, 2017, pp. 110-117. doi: 10.11648/j.pbs.20170605.16

Received: June 21, 2017; Accepted: July 10, 2017; Published: October 19, 2017

\begin{abstract}
Protection of children and adolescents health, primarily providing them with food substances and energy is one of the main objectives of the society. Purpose of research is to describe actual state of nutrition at the 15-17 years old children in Ukraine and to estimate it influence on a dynamic of morbidity with the alimentary risk factors. Materials and Methods. Investigation of average daily diets was conducted at the 15-17 years old adolescents in the comprehensive schools of Dnipro city at home and in the school canteens. Assessment of menu-layouts was carried out with using collection of recipes of the dishes and food products. Nutritive value and nutrient composition of diets was estimated with applying tables of chemical composition of foods. Analyze of diets was carried out for regulated norms of physiological needs. Results and Discussion. Dietary intake of adolescents was characterized by inadequate intake of biologically valuable products, disadvantages of a regime and diversity of meals. Energy value of daily food rations at the boys and girls did not correspond to their physiological needs on 16.58 and $14.55 \%$. Energy value of actual food ration at the boys was provided on 13.32 and $55 \%$, among the girlson 12.31 and $57 \%$, which was covered by consumption of protein, fats and carbohydrates. Diets of the adolescents were characterized by macro- and microelement deficiency: protein deficiency in the diets of boys and girls was on the level 17.81 and $17.72 \%$, carbohydrates-24.64 and 20.57. Adverse ecological factors, disturbance of an environment, a significant educational loading, lifestyle, different from the healthy life standards, unbalance by nutrients and energy value in the actual food of teenagers have a significant impact on increasing of functional disorders of a stomach-in 3.4 times, obesity in 1.2 times, anemia-on $57.6 \%$, diabetes-on $34.7 \%$ and diseases of the pancreas-on $59.7 \%$. It had been shown, that for increasing health of a youth in Ukraine should be develop the comprehensive preventive program with improvement quality of nutrition in the schools.
\end{abstract}

Keywords: Nutrition, Comprehensive Schools, Children, Feed Rations, Physiology Norms

\section{Introduction}

Review of scientific researches carried out that structure of feed of the child's population in Ukraine is characterized by serious problems, such as the following: declining level of consumption meat and meat products, milk, fish, eggs, butter, fresh vegetables and fruits, juices and increasing in the rations content of groats, pasta and bread. In a feed rations are demonstrated deficient of vitamins, especially an antioxidant row (A, C, E), macro- and microelements: iodine, iron, calcium, fluorine, selenium [4]. Estimation actual feed of schoolboys in Kyiv had been shown, that structure of food sets was inefficient and insufficient, general deficiency of green-stuffs, fruit, milk, fish and eggs was varied on the level
44.7- $86.5 \%$. It is known, that consumption of the flour, cereals, pasta was corresponded to the standard or exceeded it on $16.5-25.6 \%$ [6]. Low content of protein, basically of animal origin, was determined in the average daily rations of children in the rural districts of eight regions of Ukraine. Content of fats was varied from $80.5 \%$ to $109.0 \%$, extraordinarily was low content of vitamins A, B-group and niacin [9].

Problem of microelement and vitamin support of the children and teenagers rations of feed in Ukraine sounds very sharply. The great difference in a consumption of calcium was found out among children, depending on the region of dwelling: $27.8 \%$ of boys and $27.3 \%$ of girls were living in a large industrial city and consumed less than $400 \mathrm{mg}$ calcium 
per day [7]. The same amount of calcium per day was consumed by $45.5 \%$ of boys and $43.6 \%$ of girls, which were lived in a district center. Catastrophic were data, concerning to the peasants-children, living in the village: $75.0 \%$ of boys and $87.5 \%$ of girls consumed less than $400 \mathrm{mg}$ of calcium per day. Less than $700 \mathrm{mg}$ of calcium per day consuming $63.9 \%$ of boys, living in a large town, $95.5 \%$ - living in a district center and $100.0 \%$ - in a village (for the girls these indexes are 54.5; 85.5 and $100.0 \%$ accordingly) [5]. In Zhytomyr region, mediana of iodine deficiency makes $52.3 \pm 6.45$ $\mathrm{mcg} / \mathrm{l}$, which corresponded to easy degree of iodine insufficiency. Next analysis revealed that at $6.0 \%$ of children was found out a heavy deficit of iodine, at $28.0 \%$-moderate, at $43.0 \%$-easy and only $23.0 \%$ of children were provided with iodine [10].

In Ukraine during last years was determined a negative tendency of the basic indexes of health for children at school age. Prevalence and morbidity from all diseases among 15-17 years old teenagers during 2004-2008 years in Ukraine grew on 16.7 and $19.0 \%$, in 2016 year-on $38.87 \%$ (from 17037.06 to 23659.1 ) and on $32.32 \%$ (from 9444.78 to 12497.6 cases on 10 thousands of population) accordingly [1-3]. In 2008 year, in the diseases' prevalence structure the basic place was occupied by diseases of respiratory organs and organs of digestion, bones and muscular system and connecting tissues. In 2016 year, the following diseases take places - diseases of respiratory organs and organs of digestion, eye and additional vehicle, bones and muscular system and connecting tissues, diseases of endocrine system, disorders of feed, metabolic disturbance [8].

The school food environment in the USA is governed by a patchwork of federal, state and local laws and policies. The federal government has primary authority over the school meal programmes and has recently issued updated regulations governing the food and nutrient requirements for meals sold or served through the National School Lunch and School Breakfast Programs [11]. The school food environment-including when and where children obtain food and the types of options available during the school dayplays an important role in children's consumption patterns. Thus, childhood obesity prevention efforts often focus on altering the school food environment as a mechanism for improving student dietary intake. This work examines the role school food programs and policies play in improving children's diet, weight, and health [12].

This interim final rule amends the National School Lunch Program and School Breakfast Program regulations to establish nutrition standards for all foods sold in schools. In requires schools participating in the National School Lunch Program and School Breakfast Program to make potable water available to children at no charge in the place where lunches are served during the meal service, and in the cafeteria during breakfast meal service. This interim final rule is expected to improve the health and well-being of the Nation's children, increase consumption of healthful foods during the school day, and create an environment that reinforces the development of healthy eating habits [13].
Nutrition standards for the National School Lunch and School Breakfast Programs align them with the Dietary Guidelines for Americans. This rule requires most schools to increase the availability of fruits, vegetables, whole grains, and fat-free and low-fat fluid milk in school meals; reduce the levels of sodium, saturated fat and trans fat in meals; and meet the nutrition needs of school children within their calorie requirements [14].

Children's food intakes do not meet dietary recommendations. Foodservice managers in 398 public schools and 2,314 children (grades 1 to 12) from 287 of these schools participated in the study. Most school menus offered nonfat or $1 \%$ milk, fruit or $100 \%$ juice, and vegetables daily. Starchy vegetables were more common than dark green/orange vegetables or legumes. School lunch participants were significantly more likely than nonparticipants to consume milk, fruit, and vegetables, and significantly less likely to consume desserts, snack items, and beverages other than milk or $100 \%$ juice. At breakfast, participants were significantly more likely than nonparticipants to consume milk and fruit (mainly $100 \%$ juice), and significantly less likely to consume beverages other than milk or $100 \%$ juice. Offering more fresh fruit, whole grains, and a greater variety of vegetables could lead to additional health benefits [15].

Three health databases were searched for full-text Englishlanguage studies. Results regarding the accuracy of foodfrequency questionnaires (FFQs) and food records (FRs) were promising but limited to a single study each. Meal observations offered consistently good interrater reliability across all studies reviewed $(\mathrm{n}=11)$. Studies reporting inschool dietary outcomes $(n=47)$ used a broad range of methods, but the most frequently used methods included weighed FRs $(n=12)$, school meal recalls $(n=10)$, meal observations by trained raters $(n=8)$, and estimated FRs $(n=$ 7). The range of dietary components was greater among studies relying on school meal recalls and FRs than among studies using FFQs [16].

Good nutrition is essential to healthy childhood. The analysis is based on a nationally representative sample of 2,314 children in grades 1 through 12 from 287 public schools. The majority of public school children in the United States had nutritionally adequate diets, but $80 \%$ had excessive intakes of saturated fat and $92 \%$ had excessive intakes of sodium. School meal program participation was associated with reduced prevalence of nutrient inadequacy but with increased prevalence of excessive sodium intakes [17].

Samples of 130 public school districts that offered federally subsidized school meals, and 398 schools within those districts, participated in the study during school year 2004-2005. Most schools offered and served meals that met the standards for protein, vitamins, and minerals. Fewer than one third of schools met the standards for energy from fat or saturated fat in the average lunch, whereas three fourths or more met the fat standards in school breakfasts. For both meals, average levels of sodium were high and fiber was low 
relative to Dietary Guidelines for Americans 2005. For school meals to meet nutrient standards research should focus on reducing levels of fat and sodium and increasing fiber [18].

Diet is known to play a causal role in obesity. Increasing fruit and vegetable (FV) consumption to recommended levels is proposed to help reduce obesity. Higher intake of FV energy displaced non-FV energy, but total energy did not decrease across FV energy intake groups. High-FV-energydensity trays showed lower non-FV energy intake than lowFV-energy-density trays $(470 \pm 179$ vs. $534 \pm 219 \mathrm{kcal}$; $\mathrm{p}<0.0001)$. Trays from schools with more previous years of F2S programming decreased total and non-FV energy intake from school lunches ( $p$ for trend $<0.0001$, both). Increased FV consumption reduces non-FV energy intake, but does not reduce total energy intake [19].

The present review identified seven studies from 1990 to 2007 measuring lunchtime nutrient intake in children aged 511 years having a school meal and children having a packed lunch. Pooled estimates for each nutrient were as follows: energy intake was $543(95 \%$ CI 233, 854) kJ higher in packed lunches; total sugar intake was 14.0 (95\% CI 10.3, 17.7) $\mathrm{g}$ higher in packed lunches; non-milk extrinsic sugar intake was 11.7 (95\% CI 7.3, 16.2) g higher in packed lunches; saturated fat intake was 4.7 (95\% CI 2.4, 7.1) g higher in packed lunches and Na intake was 357 (95\% CI 174, 539) $\mathrm{mg}$ higher in packed lunches. The nutritional quality of packed lunches is poor compared with school meals. The introduction of food-based standards for school meals in 2006 has moderately improved the nutrient content of school meals, slightly widening the nutritional gap between school meals and packed lunches [20].

Purpose of research - to describe actual state of nutrition at the 15-17 years old children in Ukraine and to estimate it influence on a dynamic of morbidity with the alimentary risk factors.

\section{Materials and Methods}

The investigation was conducted in the comprehensive schools of Dnipro city and included 2406 teenagers. Research group was focused on the 1179 of boys and 1227 of girls, among them 15 years old-384 boys and 402 girls, 16 years old-393 and 411, 17 years old-402 and 414 schoolchildren accordingly. Criterion of including to research was boys and girls aged from 15 to 17 years old, which were studied in the 9-11th classes of the comprehensive schools. Criterion of exception: children at the junior age; students of colleges, lyceums and boarding-schools; presence at the boys and girls of endogenous psychical disorders and concomitant diseases in the stage of sharpening, which influence on a quality of their life, refuse from inspection and treatment. Parents of all teenagers, boys and girls signed the informed consent to participating in the research. Design of research: randomized, comparative research.

Estimation of average daily rations of feed was conducted in the home conditions and in the school dining-rooms with applying a questionnaire method in spring and autumn periods of year; menus-lay-outs - with using collection of compounding foods and ready-to-serve foods. The food value and nutrient composition of rations was determined with tables of chemical composition of food products. Analysis of rations was carried out by the regulated norms of physiology necessities [13-17].

Morbidity of teenagers (15-17 years old) in Ukraine had been taken from statistical data of Ministry of Health of Ukraine, by the Form 12 "Report on the diseases, registered for patients, who lived in a district of location of the medical - preventive establishment" in 2016, in accordance with International classification of diseases (ICD -10) [18].

For implementation results of research were applied methods of mathematical statistics. Comparison was carried out between the given data, taking from the groups of boys and girls. Statistical estimation results of research included a primary statistical analysis. For the estimation differences between groups of children was used criteria of homogenety. Statistical probability (p) was on the level $>0.95$ [19].

\section{Results and Discussion}

Structure of average daily sets of actual nutrition at the 1517 years old teenagers is presented in (table 1). Findings was shown, that assortment of teenagers food stuffs was various and did not have substantial divergences in different periods of year, except for fruit and berries, some vegetables, fresh fish, which amount increased in summer-autumn period. However, an amount of biologically valuable products was low, especially for milk and dairy products, fish and sea food, meat, bird, subproducts, fresh fruit and juices, vegetable oil and butter.

Table 1. Structure of average daily rations at the teenagers.

\begin{tabular}{lll}
\hline \multirow{2}{*}{ Name of food products } & Amount of product, gramme/day, gross & girls \\
\cline { 2 - 3 } & boys & 217 \\
\hline Bread products: & & 48 \\
bread wheat & 250 & 50 \\
bread rye & 44 & 1 \\
flour wheat & 57 & 80 \\
Starch & 1 & 57 \\
Cereals, beans, pasta, i.e. & 105 & 1 \\
Cereals & 71 & 22 \\
Beans & 1 & 219 \\
Pasta & 33 & 293 \\
Potato & 293 & \\
\hline
\end{tabular}




\begin{tabular}{lll}
\hline \multirow{2}{*}{ Name of food products } & \multicolumn{2}{l}{ Amount of product, gramme/day, gross } \\
\cline { 2 - 3 } & boys & girls \\
\hline Vegetables and water-melon & 327 & 228 \\
Fruits and berries & 74 & 89 \\
Juices from fruits \& berries and vegetables & 23 & 57 \\
Fruits dry & 4 & 51 \\
Sugar & 60 & 3 \\
Honey & 6 & 30 \\
Confectionery products & 43 & 8 \\
Butter creamy & 15 & 4 \\
Oil & 7 & 23 \\
Margarine, fat culinary & 25 & 0,7 \\
Eggs, peace & 0,9 & 138 \\
Milk and soul-milk drinks & 149 & 13 \\
Cheese & 16 & 9 \\
Sour cream & 10 & 14 \\
Cheese cottage & 13 & 153 \\
Meat, meat products, i.e. & 189 & 93 \\
meat, bird, subproducts & 115 & 60 \\
meat products (sausages, pork, etc.) & 74 & 26 \\
Fish, fish products, i.e. & 32 & 23 \\
fresh fish, frozen fish & 27 & 3 \\
fish products & 5 & 1.9 \\
Tea & 2.3 & 0.5 \\
Cacao, coffee & 0.6 & 1.0 \\
Yeasts & 1.5 & \\
\hline
\end{tabular}

In the prophylaxis of noninfectious diseases with alimentary risk factors a large value is placed by a diet, especially amount of meal's receptions and time between them. About $88.1 \%$ of teenagers having three-five meals a day, among them $43.3 \%$ of children have a three-four meals a day and $44.8 \%$-four-five meals a day; $8.9 \%$-less than three meals a day. However, there were substantial violations in a diet of 15-17 years old boys and girls: some part of teenagers were not have a breakfast at home, or did not have the lunch at school; $21.7 \%$ of teenagers in the comprehensive school did not eat at all; $44.4 \%$ were not have meals every day. Intervals between the separate receptions of meal were varied from 7 to 8 hours.

Assortment of consumed by teenagers at home meals was not various: the first meals, garnishes, dishes made from liver and other subproducts, fish, cheese, fresh vegetables and fruits (especially in winter-spring period). In menu were the same food products during a whole week, which related to family traditions and their financial possibilities. Disadvantages in the nutrition of boys and girls were found out in organization of school breakfasts: teenagers at the school dining-rooms used a free choice of food, more frequent they eating rolls, patties, pizza and tea, coffee or soft drinks.

Structure of average daily food sets at 15-17 years old teenagers was affected on the energy value and chemical composition of children rations (table 2 and 3 ).

The power value of day's rations at the teenagers was considered for boys $2669.64 \pm 77.56 \mathrm{kkal}$ (11169.77kDzh), for girls-2264.44 $\pm 47.56 \mathrm{kkal}(9474.42 \mathrm{kDzh})$, that dissatisfied the physiology necessities for teenagers on 16.58 and $14.55 \%$ accordingly. Due to the protein, fats and carbohydrates, a power value of actual rations for boys was provided on 13.32 and $55.0 \%$, for girls-on 12.31 and $57.0 \%$ accordingly, at the physiology norm 13.26 and $61.0 \%$. It testified that a basic energy source in the teenagers' feed was fats. Analysis chemical composition of their rations allowed establishing, that for students in a comprehensive school of the given agegender group the actual rations were not optimum and balanced.

Table 2. Nutriciological status of average daily rations at the boys.

\begin{tabular}{|c|c|c|c|}
\hline Nutrients & Average daily rations & Physiology Norms (PHN) & $\%$ from $\mathrm{PHN}$ \\
\hline Proteins, grammes $\left(\% \mathrm{C}^{2}\right)$ & $85.48 \pm 1.80(13)$ & $104(13)$ & 82.19 \\
\hline i.e. animal, grammes $\left(\% \mathrm{P}^{3}\right)$ & $39.62 \pm 0.99(46)$ & $52(50)$ & 76.19 \\
\hline Fats, grammes $\left(\% \mathrm{C}^{2}\right)$ & $96.20 \pm 2.63(32)$ & $94(26)$ & 102.34 \\
\hline i.e. vegetable, grammes $\left(\% \mathrm{~F}^{3}\right)$ & $20.75 \pm 1.80(22)$ & $-/ /-$ & $-/ /-$ \\
\hline Carbonhydrates, grammes $\left(\% \mathrm{C}^{2}\right)$, & $365.48 \pm 10.72(55)$ & $485(61)$ & 75.36 \\
\hline i.e. mono -, disaccharides & $108.90 \pm 8.33$ & $-/ /-$ & $-/ /-$ \\
\hline Food fibres, grammes & $16.66 \pm 1.81$ & $-/ /-$ & $-/ /-$ \\
\hline kDzh & 11169.77 & $-/ /-$ & $-/ /-$ \\
\hline Specific energy value due to proteins, fats and carbohydrates, $\%$ & $13: 32: 55$ & $13: 26: 61$ & $-/ /-$ \\
\hline \multirow[t]{2}{*}{ Correlation of proteins, fats and carbohydrates } & $1: 1.1: 4.3$ & $1: 0.9: 4.7$ & $-/ /-$ \\
\hline & Vitamins: & & \\
\hline A, mcg & $762.97 \pm 40.77$ & 1000 & 76.30 \\
\hline $\mathrm{E}, \mathrm{mg}$ & $18.02 \pm 0.65$ & 15 & 120.13 \\
\hline
\end{tabular}




\begin{tabular}{llll}
\hline Nutrients & Average daily rations & Physiology Norms (PHN) & \% from PHN \\
\hline $\mathrm{C}, \mathrm{mg}$ & $60.54 \pm 3.97$ & 80 & 75.67 \\
$\mathrm{~B} 1, \mathrm{mg}$ & $1.20 \pm 0.05$ & 1.5 & 80.00 \\
$\mathrm{~B} 2, \mathrm{mg}$ & $0.98 \pm 0.04$ & 1.8 & 54.44 \\
$\mathrm{~B}_{6}, \mathrm{mg}$ & $1.79 \pm 0.07$ & 2.0 & 89.50 \\
$\mathrm{PP}, \mathrm{mg}$ & $15.85 \pm 0.78$ & 20 & 79.25 \\
$\mathrm{~B}_{12}, \mathrm{mcg}$ & $1.83 \pm 0.02$ & 91.50 \\
folate, mcg & $132.20 \pm 8.86$ & 2.0 & 66.10 \\
$\mathrm{D}, \mathrm{mcg}$ & $1.62 \pm 0.15$ & 200 & 64.80 \\
& Mineral substances: & 2.5 & 45.31 \\
$\mathrm{Ca}, \mathrm{mg}$ & $543.70 \pm 3.71$ & 102.2 \\
$\mathrm{P}, \mathrm{mg}$ & $1226.40 \pm 7.80$ & 96.16 \\
$\mathrm{Mg}, \mathrm{mg}$ & $384.64 \pm 6.84$ & 1200 & $-/ /-$ \\
$\mathrm{Correlation} \mathrm{Ca}: \mathrm{P}: \mathrm{Mg}$ & $1: 2.2: 0.7$ & 1200 & 170.25 \\
$\mathrm{Fe}, \mathrm{mg}$ & $20.43 \pm 1.42$ & 400 & 68.40 \\
$\mathrm{Cu}, \mathrm{mg}$ & $1.71 \pm 0.20$ & $1: 1: 0.3$ & 83.33 \\
$\mathrm{Zn}, \mathrm{mg}$ & $12.50 \pm 0.61$ & 12 & 25.67 \\
$\mathrm{~J}, \mathrm{mcg}$ & $51.33 \pm 3.70$ & 2.5 & 15 \\
\hline
\end{tabular}

Notes. Recognition losses during culinary treatment of food products; $\mathrm{C}^{2}-\%$ of calorie content of food ration; $\mathrm{P}^{3}, \mathrm{~F}^{3} \%$ - general amount of proteins and fats.

Table 3. Nutriciological status of average daily rations at the girls.

\begin{tabular}{|c|c|c|c|}
\hline Nutrients & Average daily rations & Physiology Norms (PHN) & $\%$ from PHN \\
\hline Proteins, grammes $\left(\% \mathrm{C}^{2}\right)$ & $70.76 \pm 1.48(12)$ & $86(13)$ & 82.28 \\
\hline i.e. animal, grammes $\left(\% \mathrm{P}^{3}\right)$ & $33.29 \pm 0.99(47)$ & $43(50)$ & 77.42 \\
\hline Fats, grammes $\left(\% \mathrm{C}^{2}\right)$ & $77.88 \pm 3.67(31)$ & $77(26)$ & 104.14 \\
\hline i.e. vegetable, grammes $\left(\% \mathrm{~F}^{3}\right)$ & $17.46 \pm 1.08(23)$ & $-/ /-$ & $-/ /-$ \\
\hline Carbonhydrates, grammes $\left(\% \mathrm{C}^{2}\right)$ & $320.12 \pm 10.08(57)$ & $403(61)$ & 79.43 \\
\hline i.e. mono -, disaccharides & $92.20 \pm 11.62$ & $-/ /-$ & $-/ /-$ \\
\hline Food fibres, grammes & $11.70 \pm 2.18$ & $-/ /-$ & $-/ /-$ \\
\hline Power value, kkal & $264.44 \pm 47.56$ & 2650 & 85.45 \\
\hline kDzh & 9474.42 & $-/ /-$ & $-/ /-$ \\
\hline Specific energy value due to proteins, fats and carbohydrates, $\%$ & $12: 31: 57$ & $13: 26: 61$ & $-/ /-$ \\
\hline Correlation of proteins, fats and carbohydrates & $\begin{array}{l}\text { 1:1.1:4.5 } \\
\text { Vitamins: }\end{array}$ & $1: 0.9: 4.7$ & $-/ /-$ \\
\hline $\mathrm{A}, \mathrm{mcg}$ & $548.92 \pm 27.17$ & 1000 & 54.89 \\
\hline $\mathrm{E}, \mathrm{mg}$ & $13.74 \pm 0.60$ & 13 & 105.69 \\
\hline $\mathrm{C}, \mathrm{mg}$ & $51.77 \pm 2.13$ & 75 & 69.03 \\
\hline $\mathrm{B} 1, \mathrm{mg}$ & $1.01 \pm 0.02$ & 1.2 & 84.17 \\
\hline $\mathrm{B} 2, \mathrm{mg}$ & $0.79 \pm 0.04$ & 1.5 & 52.67 \\
\hline $\mathrm{B}_{6}, \mathrm{mg}$ & $1.39 \pm 0.02$ & 1.5 & 92.67 \\
\hline $\mathrm{PP}, \mathrm{mg}$ & $11.25 \pm 0.73$ & 17 & 66.18 \\
\hline $\mathrm{B}_{12}, \mathrm{mcg}$ & $1.71 \pm 0.02$ & 2.0 & 85.50 \\
\hline folate, $\mathrm{mcg}$ & $122.36 \pm 7.04$ & 180 & 67.98 \\
\hline \multirow[t]{2}{*}{$\mathrm{D}, \mathrm{mcg}$} & $0.70 \pm 0.11$ & 2.5 & 28.00 \\
\hline & Mineral substances: & & \\
\hline $\mathrm{Ca}, \mathrm{mg}$ & $494.37 \pm 6.42$ & 1200 & 41.20 \\
\hline $\mathrm{P}, \mathrm{mg}$ & $1021.43 \pm 15.03$ & 1200 & 85.12 \\
\hline $\mathrm{Mg}, \mathrm{mg}$ & $310.31 \pm 2.71$ & 300 & 103.44 \\
\hline Correlation $\mathrm{Ca}: \mathrm{P}: \mathrm{Mg}$ & $1: 2.1: 0.6$ & $1: 1: 0.4$ & $-/ /-$ \\
\hline $\mathrm{Fe}, \mathrm{mg}$ & $17,76 \pm 0,55$ & 15 & 118,40 \\
\hline $\mathrm{Cu}, \mathrm{mg}$ & $1,44 \pm 0,21$ & 2,0 & 72,00 \\
\hline $\mathrm{Zn}, \mathrm{mg}$ & $9,02 \pm 0,43$ & 13 & 69,38 \\
\hline $\mathrm{J}, \mathrm{mcg}$ & $46,12 \pm 2,65$ & 200 & 23,06 \\
\hline
\end{tabular}

Notes. Recognition losses during culinary treatment of food products; $\mathrm{C}^{2}-\%$ of calorie content of food ration; $\mathrm{P}^{3}, \mathrm{~F}^{3} \%$ - general amount of proteins and fats.

A deficiency of protein in the rations of boys and girls were carried out on the level 17.81 and $17.72 \%$, carbohydrates-24.64 and $20.57 \%$ respectively. Quota of animal protein was corresponded $46 \%$ and $47 \%$ from total amount of protein at the boys and girls, instead of recommended $50 \%$, which were at the result of consumption the insufficient amounts of animal products. Low content in the rations of food fiber $(12-17 \mathrm{~g})$ was due to a high consumption of refined carbohydrate foods in a dietary patterns of adolescents and reducing consumption of the fresh vegetables and fruits in winter-spring period. Amount of fat in the diets was on 1-2\% more than the physiological norm. However, vegetable fats were accounted $22-23 \%$ from total quantity of fats at the normal value $30 \%$. Physiological inferiority fat part of a diet characterized the content of polyunsaturated fatty acids $\omega_{6}$. From recommended $2 \%$ of energy value, content of polyunsaturated fatty acids $\omega_{6}$ at the boys and girls rations was 1.67 and $0.95 \%$ respectively. 
Imbalance of rations in the actual nutrition of teenagers was described by the ratio of basic active ingredients: protein: fat: carbohydrate was $1: 1.1: 4.3$ among the boys and 1:1.1:4.7-at the girls in a case of physiological norm for both groups 1:0.9:4.5.

At the 15-17 years old adolescents macro- and microelements deficiency, especially calcium, phosphorus (in the diets of girls), copper, zinc, iodine and unbalanced content of calcium, phosphorus and magnesium had been shown. Optimal for teenagers was ratio of calcium:phosphorus:magnesium 1:1:0.3 (for boys) and 1:1:0.4 (for girls). There was real ratio 1:2.2:0.7 and 1:2.1:0.6 at the boys and girls rations respectively. The low level of calcium in the diets of adolescents was connected with an inadequate consumption of milk and dairy products. One of the reasons was food preferences of students: more than half of them prefer milk and ice cream; don't eat cottage cheese, fermented baked milk, yogurt, cream. Negative attitude to all dairy products had been shown at $6.88 \%$ of boys and girls. Despite the fact, that diet of adolescents contains enough iron; its bioavailability was reduced due to the vegetable food intake.

In assessing nutrition with using tables of chemical composition should be minded, that on the content of nutrients in food should be affected composition and character of a group, geochemical features of the territory, climate and weather characteristics, agro-technological conditions and fertilizer. In this regard, the actual content of vitamins and minerals in different foods would differ significantly: a range of fluctuations between actual contents and calculated data was varied - for vitamin C 20-90\%, vitamin B1-66-160\%.

Content of vitamin $\mathrm{A}$ in the diets of boys and girls was 76.30 and $54.89 \%$ from the physiological range, vitamin $\mathrm{C}$ 75.67 and $69.03 \%$, vitamin B1-80.00 and $84.17 \%$, vitamin B2-54.44 and 52.67\%, vitamin B6-89.50 and 92.67\%, vitamin PP-79.25 and 66.18\%, vitamin B12-85.50 and $91.50 \%$, folate -66.10 and $67.98 \%$, vitamin D-64.80 and $28.00 \%$ respectively.

In Ukraine, significant nutrition disorders at the teenagers were largely connected with a financial crisis in the country, deterioration of economic conditions majority of the population, low purchasing activity, problem of the quality and assortment of food, well-established traditions in nutrition and low food culture of the population.

Thus, obtained data on the research, focused on the actual nutrition of 15-17 years old adolescents, showed an inadequate intake of biologically valuable products, especially milk and dairy products, fish and fish products, meat, poultry, subproducts, fresh fruits and juices, oil and butter. In a diet of boys and girls was numerous disadvantages: majority of adolescents did not have breakfast at home, not eating at school or eating not every day, the intervals between individual meals was 7-8 hours.

Teenagers eating at home monotonous food: first meals, garnish, dishes from liver and other subproducts, a few fish, cheese, fresh vegetables and fruits (especially in winterspring period); in school cafeterias - having a free choice of food, often eat buns, pies, pizza, tea, coffee or soft drinks. Energy value of daily food rations for the boys and girls did not meet to the physiological needs of adolescents on 16.58 and $14.55 \%$ respectively. Primary, an energy value of actual food ration of boys was covered on $13.32 \%$ and $55 \%$ from intake of proteins, fats and carbohydrates. Similar trend was revealed for the girls' rations-12.31 and 57.0\%. Protein was decreased in the diets of boys and girls on 17.81 and $17.72 \%$, carbohydrates-on 24.64 and $20.57 \%$ respectively. Quota of animal protein was 46 and $47 \%$ from total quantity of protein.

Low content in the rations of food fiber was due to a high consumption of refined carbohydrate products; the amount of fat in the diets was on $1-2 \%$ higher from the physiological norm. Vegetable fats accounted $22-23 \%$ of the total number of fats. Ratio of the basic ingredients, such as protein: fat: carbohydrate was $1: 1.1: 4.3$ at the boys and 1:1.1:4.7 at the girls, which was demonstrated the imbalance of rations of actual nutrition at the adolescents.

In the diets of 15-17 years old adolescents was expressive macro - and microelements deficiency, especially calcium, phosphorus (in the diets of girls), copper, zinc, iodine and unbalanced content in all diets of calcium, phosphorus and magnesium. Ratio of calcium:phosphorus: magnesium at the boys and girls rations was 1:2.2:0.7 and 1:2.1:0.6 respectively. Content of vitamin $\mathrm{A}$ in the diets of boys and girls was on 76.30 and $54.89 \%$ lower from physiological range, vitamin $\mathrm{C}-$ on 75.67 and $69.03 \%$, vitamin $\mathrm{B} 1-$ on 80.00 and $84.17 \%$, vitamin B2-on 54.44 and $52.67 \%$, vitamin B6on 89.50 and $92.67 \%$, vitamin $\mathrm{PP}-$ on 79.25 and $66.18 \%$, vitamin B12-on 85.50 and $91.50 \%$, folate-on 66.10 and $67.98 \%$, vitamin D-on 64.80 and $28.00 \%$ respectively.

Adverse ecological factors, disturbance of an environment, a significant educational loading, lifestyle, different from the healthy life standards, balance of nutrients and energy value in the actual food of teenagers have a significant impact on their health. This is confirmed by a prevalence of diseases among adolescents in Ukraine untill 2016 year and increasing its rates during the last decade [1-3, 18]. Among noninfectious diseases with alimentary risk factors at the 1517 years old adolescents in 2016, in comparison with 20042008 years, has been a significant increase in the prevalence of functional disorders of a stomach-in 3.4 times, obesity in 1.2 times, anemia-on $57.6 \%$, diabetes-on $34.7 \%$ and diseases of the pancreas-on $59.7 \%$.

The obtained results were confirmed during international project "Health and behavioral orientation of students" [2], which records a significant deterioration in the dietary habits of children and adolescents in Ukraine. In the last ten years, the majority of students, who completely refuse from a breakfast on weekdays, during training at school increased in 3 times - from 5.9\% among 10-year old to $17.2 \%$ among 17 year old. A third of respondents noted, that they consuming fruits and vegetables 4 times a week. It was provided, that in the diet should be approximately 5 meals of such products daily. They are rarely eat with a family and often visit fast food, that demonstrated about medical and social orientation 
of the given problem, which connected with family traditions [2]. As considered by A. Shvets, every year in a diet of students is significantly decreases percentage of nutritionally valuable foods such as fruits, vegetables, milk and dairy products, while increasing the consumption of carbohydrates, especially fast. This leads to the sharp damages for the public health - obesity and diabetes [2]. Therefore, the reconstruction system of prevention and disease profilactic, reducing costs of the medical services are the only strategically correct decision for the policy in the state, and for its each residents [20-22].

\section{Conclusions}

Dietary intake of adolescents in Ukraine is characterized by insufficient consumption of biologically valuable products (milk and dairy products, fish and fish products, meat, poultry, subproducts, fresh fruits and juices, vegetable oils and butter); violation of a diet (absence of breakfast at home and school, intervals between individual meals 7-8 hours); consumption at home and in school canteens monotonous food (first meals, garnish, dishes from liver and subproducts, a few fish, cheese, fresh vegetables and fruits). Energy value of daily food rations at the boys and girls did not correspond to the physiological needs of adolescents on 16.58 and $14.55 \%$ respectively. Energy value of actual food ration of boys was covered on $13.32 \%$ and $55 \%$ from intake of proteins, fats and carbohydrates.

Rations of adolescents were characterized by macro - and microelements deficiency: protein deficiency in the diets of boys and girls was 17.81 and $17.72 \%$, and carbohydrates24.64 and $20.57 \%$. Quota of animal protein was $46 \%$ and $47 \%$ from total amount of protein. Ratio of protein: fat: carbohydrate was $1: 1.1: 4.3$ and $1: 1.1: 4.7$; calcium: phosphorus: magnesium-1:2.2:0.7 and 1:2.1:0.6 respectively. Content of vitamin $\mathrm{A}$ in the diet was below from the physiological norms on 23.70 and $45.11 \%$, vitamin $\mathrm{C}$-on 24.33 and $30.97 \%$, vitamin B1-20.00 and $15.83 \%$, vitamin B2-on 45.56 and 47.33\%, vitamin B6-on 10.50 and $7.33 \%$, vitamin $\mathrm{PP}-$ on 20.75 and $33.82 \%$, vitamin B12-on 8.50 and $14.50 \%$, folate-on 33.90 and $32.02 \%$, vitamin D-on 35.20 and $72.00 \%$ respectively.

Adverse ecological factors, disturbance of an environment, a significant educational loading, lifestyle, different from the healthy life standards, balance of nutrients and energy value in the actual food of teenagers have a significant impact on increasing noninfectious diseases with alimentary risk factors, such as prevalence of functional disorders of a stomach-in 3.4 times, obesity in 1.2 times, anemia-on $57.6 \%$, diabetes-on $34.7 \%$ and diseases of the pancreas-on $59.7 \%$.

\section{References}

[1] Indicators of population health and use of health care resources in Ukraine. - K.: Ministry of Health in Ukraine, 2009. - 328 p. [Electronic resource]. - Mode of access: [WWW-document]. URL http: // www. ifp. Kiev. ua.
[2] Peresypkina T. V. Dynamics of the health status of adolescents in Ukraine. Journal "Child's Health" 1 (52) 2014. [Electronic resource]. - Mode of access: http://www.mifua.com/archive/article/38094.

[3] Kazakevich V. K. New approaches to the assessment of health status of school-age children. Sovremennaya pediatria. 2016. 4 (76):44-46; doi 10.15574/SP.2016.76.44.

[4] Francesco Branca, Ellen Piwoz, Werner Schultink, Lucy Martinez Sullivan. Nutrition and health in women, children, and adolescent girls. BMJ 2015; 351 doi: https://doi.org/10.1136/bmj.h4173 (Published 14 September 2015) Cite this as: BMJ 2015; 351:h4173.

[5] Klimowska L. O. Prevention of violations of microelement homeostasis as a component of health monitoring system of adolescents: convention analysis of the problem (part I). Hygiene of populated areas. 2008. 51: 388-398.

[6] Kulchitskaya W. P., Grigorenko A. A., Camerun I. V. [et al.]. Nutritional status of children at the preschool and school-age and hygienic actions for its improvement. Hygienic science and practice at a turn of the centuries: materials of XIV Congress of hygienists in Ukraine (Dnepropetrovsk, 19-21 May 2004) - P. 366-368

[7] Kostenko A. M., Morgun A. M., Dyakova T. M. Hygienic assessment of actual nutrition of students at school № 92 in the Hortitsky region of Zaporozhya. Hygienic science and practice at a turn of the centuries: materials of XIV Congress of hygienists in Ukraine (Dnepropetrovsk, 19-21 May 2004) P. 419-422.

[8] Skaletska N. M. Hygienic evaluation of nutrition of children in primary school. Hygiene of populated areas. 2009. 54: 262-264.

[9] Gulich N. P., Olszewski A. D., Yatchenko A. A. [et al.]. Modern approaches to enrichment by micronutrients food products of mass consumption. Hygiene of populated areas. 2008. 51:318-322.

[10] Parats A. M. Status and prevention of iodine deficient diseases in children in Zhytomyr region. Hygiene of populated areas. 2008. 52: 403-411.

[11] School food and nutrition policy, monitoring and evaluation in the USA / Hirschman J, Chriqui JF. // Public Health Nutr. 2013 Jun; 16 (6):982-8.

[12] The School Food Environment and Obesity Prevention: Progress Over the Last Decade / Welker E, Lott M, Story M.// Curr Obes Rep. 2016 Jun;5 (2):145-55.

[13] National School Lunch Program and School Breakfast Program: nutrition standards for all foods sold in school as required by the Healthy, Hunger-Free Kids Act of 2010 . Interim final rule. Food and Nutrition Service, USDA / Fed Regist. 2013 Jun 28; 78 (125):39067-120.

[14] Nutrition standards in the National School Lunch and School Breakfast Programs. Final rule. Food and Nutrition Service (FNS), USDA / Fed Regist. 2012 Jan 26; 77 (17):4088-167.

[15] School meals: types of foods offered to and consumed by children at lunch and breakfast / Condon EM, Crepinsek MK, Fox MK. //J Am Diet Assoc. 2009 Feb; 109 (2 Suppl):S67-78.

[16] A Systematic Review of Methods to Assess Children's Diets in the School Context / Tugault-Lafleur CN, Black JL, Barr SI.// Adv Nutr. 2017 Jan 17; 8 (1):63-79. 
[17] Nutritional quality of the diets of US public school children and the role of the school meal programs / Clark MA, Fox MK // J Am Diet Assoc. 2009 Feb; 109 (2 Suppl):S44-56.

[18] Meals offered and served in US public schools: do they meet nutrient standards? / Crepinsek MK, Gordon AR, McKinney PM, Condon EM, Wilson A. // J Am Diet Assoc. 2009 Feb; 109 (2 Suppl):S31-43.
[19] Fruits and vegetables displace, but do not decrease, total energy in school lunches / Bontrager Yoder AB, Schoeller DA. // Child Obes. 2014 Aug; 10 (4):357-64.

[20] A comparison of British school meals and packed lunches from 1990 to 2007: meta-analysis by lunch type / Evans CE, Cleghorn CL, Greenwood DC, Cade JE. // Br J Nutr. 2010 Aug; 104 (4):474-87. 